\title{
ANALISIS KINERJA KEUANGAN DENGAN MENGGUNAKAN COMMON SIZE PADA PERUSAHAAN OTOMOTIF YANG TERDAFTAR DI BURSA EFEK INDONESIA (BEI) TAHUN 2016
}

\author{
Ayu K. Krisna Prihastuti ${ }^{1}$, Kadek Rai Suwena ${ }^{2}$, I Nyoman Sujana ${ }^{3}$ \\ Jurusan Pendidikan Ekonomi, Fakultas Ekonomi \\ Universitas Pendidikan Ganesha Singaraja, \\ Indonesia \\ e-mail: krisnaprihastuti@gmail.com',kadek_suwena@yahoo.co.id², \\ nyoman_sujana@undikshā.ac.id ${ }^{3}$
}

\begin{abstract}
Abstrak
Penelitian ini bertujuan untuk mengetahui kinerja keuangan dengan menggunakan common size pada perusahaan otomotif yang terdaftar di Bursa Efek Indonesia tahun 2016 ditinjau dari neraca dan laporan laba rugi. Penelitian ini merupakan penelitian deskriptif kuantitatif. Data dikumpulkan dengan metode dokumentasi dan analisis data yang digunakan yaitu analisis persentase per komponen atau common size. Hasil penelitian menunjukkan bahwa common size ditinjau dari neraca, ada enam perusahaan otomotif yang mengalokasikan dana untuk aktiva sebagian besar dari utang dan tujuh perusahaan otomotif mengalokasikan dana untuk aktiva dari modal sendiri sehingga meningkatkan margin of safety bagi kreditur dan menguatkan posisi keuangan perusahaan. Common size ditinjau dari laporan laba rugi, terdapat sepuluh perusahaan otomotif mengalami peningkatan pada laba bersihnya sehingga kinerja keuangan perusahaan semakin baik dan tiga perusahaan otomotif lainnya memiliki kinerja keuangan kurang baik karena mengalami penurunan pada laba bersihnya.
\end{abstract}

Kata kunci: common size, kinerja keuangan, laporan laba rugi, neraca.

\begin{abstract}
This research aims to understand financial performance by using common size in automotive companies listed in Indonesia Stock Exchange in 2016 viewed from the balance sheet and reviewed from the income statement. This research is a quantitative descriptive research. Data collected by method of documentation and data analysis used is percentage analysis per component or common size. The result show that common size is viewed from the balance sheet, there are six automotive companies that allocate funds for assets mostly from debt and seven automotive companies allocate funds for assets of their own capital thus increasing the margin of safety for creditors and strengthening the company's financial position. Common size is reviewed from the income statement, there are ten automotive companies experienced an increase in net profit so that the financial performance of the company getting better and three other automotive companies have poor financial performance due to a decrease in net income.
\end{abstract}

Keywords: common size, financial performance, income statement, balance sheet.

\section{PENDAHULUAN}

Dalam perkembangan dunia usaha yang semakin maju, bidang keuangan menjadi bidang yang penting bagi suatu perusahaan. Perekonomian yang semakin kompleks dan tidak menentu, diikuti dengan persaingan antar perusahaan yang semakin ketat, membuat perlunya dilakukan suatu penilaian pada bidang keuangan pada setiap perusahaan.

Penilaian pada kinerja keuangan perusahaan dapat dilakukan dengan membandingkan suatu perusahaan dengan perusahaan pesaingnya yang bergerak pada bidang jasa sejenis. Hal ini tentu saja sangat berguna bagi 
investor dalam mengetahui kondisi perusahaan-perusahaan tertentu untuk menentukan mana yang lebih baik dan lebih menguntungkan dilihat dari perbandingan kinerja keuangan perusahaan. Kinerja keuangan adalah penentuan ukuran-ukuran tertentu yang dapat mengukur keberhasilan suatu organisasi atau perusahaan dalam menghasilkan laba (Sawir, 2005). Selain itu menurut Fahmi (2012) kinerja keuangan adalah suatu analisis yang dilakukan untuk melihat sejauh mana suatu perusahaan telah menjalankan perusahaan dengan menggunakan aturan-aturan pelaksanaan keuangan secara baik dan benar. Dengan melakukan penilaian kinerja keuangan, maka akan diperoleh informasi mengenai kondisi dan posisi keuangan perusahaan.

Kinerja keuangan dapat dikatakan baik jika dapat memenuhi persyaratan yang ditetapkan sesuai dengan prinsip akuntansi Indonesia, yaitu relevan, dapat dimengerti, netral, tepat waktu, dapat dibandingkan dan lengkap. Kinerja keuangan suatu perusahaan dapat dinilai dari laporan keuangannya. "Laporan keuangan adalah laporan yang menunjukkan kondisi keuangan perusahaan pada saat ini dalam suatu periode tertentu" (Kasmir, 2016a:66). Laporan keuangan tidak hanya sebagai alat penguji saja tetapi juga sebagai dasar untuk menentukan atau menilai posisi keuangan perusahaan, dimana dengan hasil analisa tersebut pihakpihak yang berkepentingan dapat mengambil keputusan yang tepat. Menurut Kamaludin dan Indriani (2012) laporan keuangan adalah hasil akhir dari suatu proses pencatatan yang merupakan suatu ringkasan dari transaksi keuangan yang terjadi selama tahun buku yang bersangkutan.

Berbicara mengenai laporan keuangan muncul suatu permasalahan yaitu sulitnya memprediksi apakah suatu perusahaan mengalami kenaikan atau penurunan pada masing-masing pos keuangan, karena setiap nilai yang naik setiap tahunnya belum tentu persentasenya naik juga. Pos-pos keuangan dalam laporan keuangan sulit diprediksi, sehingga tidak dapat membandingkan atau tidak dapat memperoleh gambaran tentang perubahan dalam masing-masing unsur dari tahun ke tahun dalam hubungannya dengan total aktiva, total utang dan modal sendiri, serta jumlah atau nilai penjualan neto (Jumingan, 2014). Maka dari itu, perlu diadakannya sebuah analisis laporan keuangan dengan cara menilai pos-pos keuangan dalam laporan keuangan pada suatu periode menjadi persentase, agar dapat diketahui apakah perusahaan tersebut mengalami kenaikan atau sebaliknya. Analisis tersebut adalah analisis persentase per komponen atau yang sering disebut dengan common size.

Common size mengubah angkaangka yang ada dalam neraca dan laporan laba rugi menjadi persentase berdasarkan dasar tertentu (Husnan, 2011). Menurut Hanafi dan Halim (2009), analisis common size disusun dengan jalan menghitung tiap-tiap rekening dalam laporan laba rugi dan neraca menjadi proporsi dari total penjualan (untuk laporan laba rugi) atau dari total aktiva (untuk neraca). Selain itu, menurut Munawir (2010) common size adalah suatu metode analisis untuk mengetahui persentase investasi pada masing-masing aset terhadap total asetnya, juga untuk mengetahui struktur permodalannya dan komposisi perongkosan yang terjadi dihubungkan dengan jumlah penjualannya.

Penyajian dalam bentuk common size akan mempermudah bagi pembaca laporan keuangan untuk memperhatikan perubahan-perubahan yang terjadi pada neraca dan laporan laba rugi. Perubahan yang terjadi tidak akan diketahui baik atau buruknya tanpa melihat proporsi dari setiap pos terhadap total yang dijadikan sebagai angka dasar perhitungan persentase. Dengan adanya persentase per komponen pada laporan keuangan sangat bermanfaat bagi penganalisis yang sedang mempelajari keadaan keuangan jangka pendek dan hasil usaha perusahaan, khususnya dalam 
membuat perbandingan di antara perusahaan sejenis dan perbandingan dengan rasio industri (Jumingan, 2014). Selain itu prosedur yang ada dalam analisis laporan keuangan dengan menggunakan common size disebut juga sebagai analisis vertikal karena melakukan evaluasi akun dari atas ke bawah atau dari bawah ke atas dalam laporan keuangan yang ada pada perusahaan (Hery, 2012).

Common size juga dapat menunjukkan distribusi dari utang dan modal sendiri (yang merupakan sumber modal yang ditanamkan dalam berbagai bentuk aktiva). Menurut Jumingan (2014) apabila persentase total utang terlalu besar sehingga menimbulkan beban berat bagi perusahaan dan rendahnya margin of safety bagi kreditur dan apabila proporsi modal sendiri lebih besar dibandingkan dengan proporsi modal pinjaman (utang) akan meningkatkan margin of safety bagi kreditur dan menguatkan posisi keuangan perusahaan.

Common size pada laporan laba rugi, setiap akun terkait dengan angka kunci penjualan. Dalam berbagai tingkatan, penjualan mempengaruhi hampir seluruh beban dan bermanfaat untuk mengetahui berapa persen dari penjualan diwakili oleh tiap-tiap akun beban. Dalam laporan laba rugi, jika persentase harga pokok penjualan menurun akan mengakibatkan naiknya persentase gross margin (persentase laba bruto dari nilai penjualan neto) sehingga mencerminkan keberhasilan strategi pemasaran, begitupun sebaliknya (Jumingan, 2014). Berhasilnya suatu perusahaan dalam menjalankan usahanya dilihat dari laba bersihnya. Meningkatnya laba bersih suatu perusahaan menunjukkan kemampuan perusahaan dalam menghasilkan laba bersih berdasarkan tingkat penjualannya semakin baik sehingga kinerja keuangan perusahaan semakin baik.

Pada penelitian ini yang akan dijadikan objek penelitian ialah perusahaan di Indonesia yang bergerak di industri otomotif. Perusahaan otomotif yang telah go public dan terdaftar pada Bursa Efek Indonesia ada sebanyak 13 perusahaan (www.sahamok.com). Banyaknya perusahaan otomotif membuat persaingan antar perusahaan semakin ketat, yang tentunya akan berdampak langsung terhadap perolehan laba perusahaan sehingga akan mempengaruhi kinerja keuangan perusahaan dan dapat menunjukkan perbandingan perusahaan otomotif yang satu dengan lainnya sehingga akan diketahui apakah kinerja suatu perusahaan mengalami peningkatan atau menunjukkan penurunan. Seperti pada tahun 2015, laba bersih turun $15,2 \%$ dibandingkan periode sama tahun sebelumnya. Penurunan laba bersih tersebut disebabkan turunnya penjualan di industri otomotif secara keseluruhan. Kondisi itu mempengaruhi langsung kinerja perseroan yang memproduksi suku cadang otomotif (Rochimawati, 2015). Penurunan laba bersih juga ditunjukkan pada kuartal I tahun 2016 menjadi 3\% menjadi Rp. 1,6 triliun. Secara keseluruhan, permintaan otomotif melemah selama tiga bulan pertama tahun 2016 (Afrianti, 2016). Akan tetapi jika dilihat perolehan laba sepanjang tahun 2016, kinerja perusahaan otomotif cukup baik, dengan pencapaian pangsa pasar mobil dan sepeda motor (Arifin, 2017).

Berdasarkan uraian latar belakang di atas, maka penulis ingin menganalisis kinerja keuangan perusahaan otomotif dengan menggunakan common size. Maka penelitian yang penulis lakukan dengan judul analisis kinerja keuangan dengan menggunakan common size pada perusahaan otomotif yang terdaftar di Bursa Efek Indonesia (BEI) tahun 2016.

Berdasarkan latar belakang tersebut, maka dirumuskan masalah penelitian ini sebagai berikut. (1) Bagaimana kinerja keuangan dengan menggunakan common size pada perusahaan otomotif yang terdaftar di Bursa Efek Indonesia (BEI) tahun 2016 ditinjau dari neraca? (2) Bagaimana kinerja keuangan dengan menggunakan 
common size pada perusahaan otomotif yang terdaftar di Bursa Efek Indonesia (BEI) tahun 2016 ditinjau dari laporan laba rugi?

Berdasarkan rumusan masalah di atas, maka tujuan dari penelitian ini adalah untuk mengetahui (1) kinerja keuangan dengan menggunakan common size pada perusahaan otomotif yang terdaftar di Bursa Efek Indonesia (BEI) tahun 2016 ditinjau dari neraca dan (2) kinerja keuangan dengan menggunakan common size pada perusahaan otomotif yang terdaftar di Bursa Efek Indonesia (BEl) tahun 2016 ditinjau dari laporan laba rugi.

\section{METODE}

Rancangan penelitian yang digunakan dalam penelitian ini adalah penelitian deskriptif dengan pendekatan kuantitatif. Penelitian ini memaparkan kinerja keuangan perusahaan otomotif yang telah terdaftar di Bursa Efek Indonesia tahun 2016 yang dikaji dengan menggunakna common size.

Subjek dalam penelitian ini adalah perusahaan otomotif yang terdaftar di Bursa Efek Indonesia tahun 2016 sebanyak 13 perusahaan yaitu PT Astra International Tbk (ASII), PT Astra Otoparts Tbk (AUTO), PT Garuda Metalindo Tbk (BOLT), PT Indo Kordsa Tbk d.h Branta Mulia Tbk (BRAM), PT Goodyear Indonesia Tbk (GDYR), PT Gajah Tunggal Tbk (GJTL), PT Indomobil Sukses International Tbk (IMAS), PT Indospring Tbk (INDS), PT Multi Prima Sejahtera Tbk d.h Lippo Enterprises Tbk (LPIN), PT Multistrada Arah Sarana Tbk (MASA), PT Nipress Tbk (NIPS), PT Prima Alloy Steel Universal Tbk (PRAS), dan PT Selamat Sempurna Tbk (SMSM). Objek dari penelitian ini adalah berupa data laporan keuangan tahunan perusahaan otomotif tahun 2016 berupa neraca dan laporan laba rugi.

Jenis data yang digunakan dalam penelitian ini adalah data kuantitatif. Data kuantitatif dalam penelitian ini berupa data laporan keuangan tahunan perusahaan otomotif yang terdiri dari neraca dan laporan laba rugi pada tahun 2016 dengan tahun 2015 sebagai pembandingnya.

Sumber data yang digunakan dalam penelitian ini adalah data sekunder. Data sekunder yang digunakan dalam penelitian ini diambil dari dokumen laporan keuangan tahunan perusahaan otomotif yang dipublikasikan di Bursa Efek Indonesia tahun 2016.

Teknik pengumpulan data dalam penelitian ini menggunakan teknik dokumentasi. Dokumentasi dalam penelitian ini digunakan untuk mengumpulkan data laporan keuangan tahunan perusahaan otomotif tahun 2016 berupa neraca dan laporan laba rugi dengan mengakses www.idx.co.id.

Teknik analisis data yang digunakan dalam penelitian ini adalah analisis persentase per komponen atau common size. Adapun langkah-langkah dalam perhitungan analisis persentase per komponen atau common size menurut Jumingan (2014) yaitu yang pertama, nyatakan terlebih dahulu total aktiva, total pasiva (utang ditambah dengan modal sendiri) dan total penjualan neto menjadi $100 \%$. Kedua, hitunglah rasio persentase dari masingmasing pos/komponen yang ada pada neraca dengan cara membagi jumlah rupiah masing-masing pos/komponen neraca dengan total aktiva untuk pospos aktiva dan total pasiva untuk pospos pasiva. Berikut rumus yang dapat digunakan.

Aktiva:

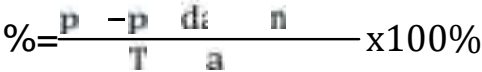

(Jumingan, 2014)

Pasiva:

$\%=\frac{\mathrm{p}-\mathrm{p} \quad \mathrm{di} \quad \mathrm{n}}{\mathrm{T}} \mathrm{p}-\mathrm{p} 100 \%$

(Jumingan, 2014)

Ketiga, hitunglah rasio persentase dari masing-masing pos/komponen yang ada pada laporan laba rugi dengan cara membagi jumlah rupiah masing-masing pos/komponen laporan laba rugi itu dengan total penjualan neto. Berikut rumus yang dapat digunakan.

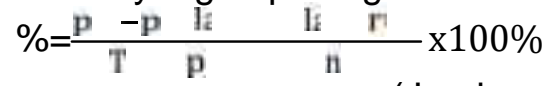

(Jumingan, 2014) 
HASIL DAN PEMBAHASAN Hasil

Kinerja keuangan dengan menggunakan common size ditinjau dari neraca (laporan posisi keuangan) pada tiga belas perusahaan otomotif yang terdaftar di Bursa Efek Indonesia (BEI) tahun 2016 dan tahun 2015 sebagai pembandingnya, dapat dilihat pada tabel 1 berikut.

Tabel 1. Common Size ditinjau dari Neraca pada Perusahaan Otomotif

\begin{tabular}{|c|c|c|c|c|c|c|c|}
\hline \multirow{2}{*}{$\begin{array}{c}\text { Perusahaan } \\
\text { viviluuu! }\end{array}$} & \multirow[t]{2}{*}{ Tahun } & \multicolumn{6}{|c|}{ POS } \\
\hline & & $\begin{array}{l}\text { Aktiva } \\
\text { Lancar }\end{array}$ & $\begin{array}{l}\text { Aktiva } \\
\text { Tidak } \\
\text { Lancar }\end{array}$ & $\begin{array}{l}\text { Total } \\
\text { Aktiva }\end{array}$ & $\begin{array}{c}\text { Utang } \\
\text { (Liabilitas) }\end{array}$ & $\begin{array}{c}\text { Modal } \\
\text { (Ekuitas) }\end{array}$ & $\begin{array}{l}\text { Total } \\
\text { Pasiva }\end{array}$ \\
\hline \multirow{2}{*}{$\begin{array}{l}\text { PT Astra } \\
\text { International Tbk }\end{array}$} & 2015 & $42,85 \%$ & $57,15 \%$ & $100,00 \%$ & $48,45 \%$ & $51,55 \%$ & $00,00 \%$ \\
\hline & 016 & $42,16 \%$ & $7,84 \%$ & $00,00 \%$ & $46,57 \%$ & $3,43 \%$ & $00,00 \%$ \\
\hline \multirow{2}{*}{$\begin{array}{l}\text { PT Astra } \\
\text { Otoparts Tbk }\end{array}$} & & $33,45 \%$ & , $55 \%$ & $0,00 \%$ & $29,26 \%$ & $70,74 \%$ & $00,00 \%$ \\
\hline & 16 & $33,56 \%$ & $6,44 \%$ & $0,00 \%$ & $27,89 \%$ & $72,11 \%$ & $00,00 \%$ \\
\hline \multirow{2}{*}{$\begin{array}{l}\text { PT Garuda } \\
\text { Metalindo Tbk }\end{array}$} & & $53,00 \%$ & $47,00 \%$ & $100,00 \%$ & $17,21 \%$ & $82,79 \%$ & $100,00 \%$ \\
\hline & 16 & $52,77 \%$ & $47,23 \%$ & $100,00 \%$ & $13,20 \%$ & $86,80 \%$ & $100,00 \%$ \\
\hline \multirow{2}{*}{$\begin{array}{l}\text { PT Indo Kordsa Tbk } \\
\text { d.h Branta Mulia Tbk }\end{array}$} & & $34,98 \%$ & $65,02 \%$ & $100,00 \%$ & $37,32 \%$ & $62,68 \%$ & $0,00 \%$ \\
\hline & 16 & $38,04 \%$ & $61,96 \%$ & $100,00 \%$ & $33,21 \%$ & $66,79 \%$ & $100,00 \%$ \\
\hline \multirow{2}{*}{$\begin{array}{l}\text { PT Goodyear } \\
\text { Indonesia Tbk }\end{array}$} & & $42,45 \%$ & $57,55 \%$ & $100,00 \%$ & $53,50 \%$ & $6,50 \%$ & $00,00 \%$ \\
\hline & 2016 & $41,51 \%$ & $58,49 \%$ & $100,00 \%$ & $50,13 \%$ & $49,87 \%$ & $100,00 \%$ \\
\hline \multirow{2}{*}{$\begin{array}{l}\text { PT Gajah } \\
\text { Tunggal Tbk }\end{array}$} & & $37,71 \%$ & $62,29 \%$ & $100,00 \%$ & $69,19 \%$ & $30,81 \%$ & $100,00 \%$ \\
\hline & 2016 & $40,20 \%$ & $59,80 \%$ & $100,00 \%$ & $68,72 \%$ & $31,28 \%$ & $100,00 \%$ \\
\hline \multirow{2}{*}{$\begin{array}{l}\text { PT Indomobil Sukses } \\
\text { International I bk }\end{array}$} & 2015 & $49,04 \%$ & $50,96 \%$ & $100,00 \%$ & $73,06 \%$ & $26,94 \%$ & $100,00 \%$ \\
\hline & 2016 & $45,41 \%$ & $54,59 \%$ & $100,00 \%$ & $73,82 \%$ & $26,18 \%$ & $100,00 \%$ \\
\hline \multirow[t]{2}{*}{ PT Indospring Tbk } & & $38,88 \%$ & $61,12 \%$ & $100,00 \%$ & $24,86 \%$ & $75,14 \%$ & $100,00 \%$ \\
\hline & 2016 & $39,63 \%$ & $60,37 \%$ & $100,00 \%$ & $16,52 \%$ & $83,48 \%$ & $100,00 \%$ \\
\hline \multirow{4}{*}{$\begin{array}{l}\text { PT Multi Prima } \\
\text { Sejahtera Tbk } \\
\text { d.h Lippo } \\
\text { Enterprises Tbk } \\
\text { PT Multistrada Arah } \\
\text { Sarana Tbk }\end{array}$} & & $44,71 \%$ & $55,29 \%$ & $100,00 \%$ & $64,05 \%$ & $35,95 \%$ & $100,00 \%$ \\
\hline & & $39,15 \%$ & $60,85 \%$ & $100,00 \%$ & $89,20 \%$ & $10,80 \%$ & $100,00 \%$ \\
\hline & 2015 & $26,58 \%$ & $73,42 \%$ & $100,00 \%$ & $42,27 \%$ & $57,73 \%$ & $100,00 \%$ \\
\hline & & $24,89 \%$ & $75,11 \%$ & $100,00 \%$ & $44,41 \%$ & $55,59 \%$ & $100,00 \%$ \\
\hline \multirow[t]{2}{*}{ PT Nipress Tbk } & 2015 & $45,31 \%$ & $54,69 \%$ & $100,00 \%$ & $60,65 \%$ & $39,35 \%$ & $100,00 \%$ \\
\hline & & $46,42 \%$ & $53,58 \%$ & $100,00 \%$ & $52,61 \%$ & $47,39 \%$ & $100,00 \%$ \\
\hline \multirow{2}{*}{$\begin{array}{l}\text { PT Prima Alloy Steel } \\
\text { Universal Tbk }\end{array}$} & 2015 & $42,91 \%$ & $57,09 \%$ & $100,00 \%$ & $52,88 \%$ & $47,12 \%$ & $100,00 \%$ \\
\hline & & $43,03 \%$ & $56,97 \%$ & $100,00 \%$ & $56,59 \%$ & $43,41 \%$ & $100,00 \%$ \\
\hline \multirow{2}{*}{$\begin{array}{l}\text { PT Selamat } \\
\text { Sempurna Tbk }\end{array}$} & 2015 & $61,64 \%$ & $38,36 \%$ & $100,00 \%$ & $35,13 \%$ & $64,87 \%$ & $100,00 \%$ \\
\hline & 2016 & $64,50 \%$ & $35,50 \%$ & $100,00 \%$ & $29,92 \%$ & $70,08 \%$ & $100,00 \%$ \\
\hline
\end{tabular}

Berdasarkan perbandingan persentase per komponen (common size) pada neraca tahun 2016 dan tahun 2015 sebagai pembandingnya menunjukkan bahwa terdapat salah satu perusahaan yang sangat banyak menggunakan aktiva tidak lancar sebagai modal perusahaan bila dibandingkan dengan aktiva lancar yaitu
PT Multistrada Arah Sarana Tbk (MASA). Sedangkan perusahaan yang sangat banyak menanamkan modal perusahaan dalam bentuk aktiva lancar bila dibandingkan aktiva tidak lancar adalah PT Selamat Sempurna Tbk (SMSM).

Pada komposisi pasiva, terlihat bahwa utang dan modal sendiri yang 
dimiliki oleh masing-masing perusahaan mengalami peningkatan maupun penurunan. Salah satu perusahaan otomotif yang cenderung mengalami peningkatan pada persentase utang dan mengalami penurunan pada persentase modal sendiri adalah pada PT Multistrada Arah Sarana Tbk (MASA). Sedangkan perusahaan yang mengalami perubahan besar tahun 2015 dan 2016 pada persentase utang yang cenderung mengalami penurunan dan persentase modal sendiri yang cenderung mengalami peningkatan yang tinggi adalah pada PT Indospring Tbk (INDS).

Selain untuk mengetahui kinerja keuangan dengan menggunakan common size ditinjau dari neraca, penelitian ini juga untuk mengetahui common size ditinjau dari laporan laba rugi. Common size pada laporan laba rugi pada tiga belas perusahaan otomotif yang terdaftar di Bursa Efek Indonesia (BEI) tahun 2016 dan tahun 2015 sebagai pembandingnya, dapat dilihat pada tabel 2 berikut.

Tabel 2. Common Size ditinjau dari Laporan Laba Rugi pada Perusahaan Otomotif

\begin{tabular}{|c|c|c|c|c|c|}
\hline \multirow[t]{2}{*}{ Perusahaan Otomotif } & \multirow[t]{2}{*}{ Tahun } & \multicolumn{4}{|c|}{ POS } \\
\hline & & $\begin{array}{l}\text { Penjualan } \\
\text { Bersih }\end{array}$ & $\begin{array}{c}\text { Beban } \\
\text { Pokok } \\
\text { Penjualan }\end{array}$ & Laba Kotor & Laba Bersih \\
\hline \multirow[t]{2}{*}{ PT Astra International Tbk } & 2015 & $100,00 \%$ & $(80,07) \%$ & $19,93 \%$ & $8,48 \%$ \\
\hline & 2016 & $100,00 \%$ & $(79,88) \%$ & $20,12 \%$ & $10,11 \%$ \\
\hline \multirow[t]{2}{*}{ PT Astra Otoparts Tbk } & 2015 & $100,00 \%$ & $(85,24) \%$ & $14,76 \%$ & $2,75 \%$ \\
\hline & 2016 & $100,00 \%$ & $(85,53) \%$ & $14,47 \%$ & $3,77 \%$ \\
\hline \multirow[t]{2}{*}{ PT Garuda Metalindo Tbk } & 2015 & $100,00 \%$ & $(72,09) \%$ & $27,91 \%$ & $11,38 \%$ \\
\hline & 2016 & $100,00 \%$ & $(73,88) \%$ & $26,12 \%$ & $12,20 \%$ \\
\hline \multirow{2}{*}{$\begin{array}{l}\text { PT Indo Kordsa Tbk d.h } \\
\text { Branta Mulia Tbk }\end{array}$} & 2015 & $100,00 \%$ & $(83,02) \%$ & $16,98 \%$ & $6,04 \%$ \\
\hline & 2016 & $100,00 \%$ & $(79,50) \%$ & $20,50 \%$ & $10,12 \%$ \\
\hline \multirow[t]{2}{*}{ PT Goodyear Indonesia Tbk } & 2015 & $100,00 \%$ & $(89,57) \%$ & $10,43 \%$ & $(0,07) \%$ \\
\hline & 2016 & $100,00 \%$ & $(88,85) \%$ & $11,15 \%$ & $1,07 \%$ \\
\hline \multirow[t]{2}{*}{ PT Gajah Tunggal Tbk } & 2015 & $100,00 \%$ & $(79,77) \%$ & $20,23 \%$ & $(2,42) \%$ \\
\hline & 2016 & $100,00 \%$ & $(76,56) \%$ & $23,44 \%$ & $4,60 \%$ \\
\hline \multirow{2}{*}{$\begin{array}{l}\text { PT Indomobil Sukses } \\
\text { International Tbk }\end{array}$} & 2015 & $100,00 \%$ & $(84,82) \%$ & $15,18 \%$ & $(0,12) \%$ \\
\hline & 2016 & $100,00 \%$ & $(82,28) \%$ & $17,72 \%$ & $(2,08) \%$ \\
\hline \multirow[t]{2}{*}{ PT Indospring Tbk } & 2015 & $100,00 \%$ & $(88,88) \%$ & $11,12 \%$ & $0,12 \%$ \\
\hline & 2016 & $100,00 \%$ & $(84,49) \%$ & $15,51 \%$ & $3,03 \%$ \\
\hline \multirow{2}{*}{$\begin{array}{l}\text { PT Multi Prima Sejahtera Tbk } \\
\text { d.h Lippo Enterprises Tbk }\end{array}$} & 2015 & $100,00 \%$ & $(71,01) \%$ & $28,99 \%$ & $(23,36) \%$ \\
\hline & 2016 & $100,00 \%$ & $(63,56) \%$ & $36,44 \%$ & $(45,18) \%$ \\
\hline \multirow{2}{*}{$\begin{array}{l}\text { PT Multistrada Arah Sarana } \\
\text { Tbk }\end{array}$} & 2015 & $100,00 \%$ & $(92,54) \%$ & $7,46 \%$ & $(11,33) \%$ \\
\hline & 2016 & $100,00 \%$ & $(87,57) \%$ & $12,43 \%$ & $(2,92) \%$ \\
\hline \multirow[t]{2}{*}{ PT Nipress Tbk } & 2015 & $100,00 \%$ & $(81,51) \%$ & $18,49 \%$ & $3,10 \%$ \\
\hline & 2016 & $100,00 \%$ & $(82,82) \%$ & $17,18 \%$ & $6,32 \%$ \\
\hline \multirow{2}{*}{$\begin{array}{l}\text { PT Prima Alloy Steel } \\
\text { Universal Tbk }\end{array}$} & 2015 & $100,00 \%$ & $(82,27) \%$ & $17,73 \%$ & $1,37 \%$ \\
\hline & 2016 & $100,00 \%$ & $(80,02) \%$ & $19,98 \%$ & $(0,73) \%$ \\
\hline \multirow[t]{2}{*}{ PT Selamat Sempurna Tbk } & 2015 & $100,00 \%$ & $(68,98) \%$ & $31,02 \%$ & $16,46 \%$ \\
\hline & 2016 & $100,00 \%$ & $(67,56) \%$ & $32,44 \%$ & $17,44 \%$ \\
\hline
\end{tabular}


Berdasarkan perbandingan persentase per komponen (common size) pada laporan laba rugi tahun 2016 dan tahun 2015 sebagai pembandingnya, menunjukkan bahwa persentase beban pokok penjualan relatif lebih besar bila dbandingkan dengan persentase laba kotor. Akan tetapi pada persentase beban pokok penjualan dan laba kotor sama-sama mengalami peningkatan maupun penurunan pada tahun 2015 dan tahun 2016. Perubahan yang paling besar terjadi pada PT Multi Prima Sejahtera Tbk d.h Lippo Enterprises Tbk (LPIN) yang mengalami penurunan pada persentase beban pokok penjualan dan mengalami peningkatan pada persentase laba kotor sebesar $7,45 \%$.

Pada persentase laba bersih ada salah satu perusahaan otomotif yang mengalami peningkatan sangat tinggi yaitu pada PT Gajah Tunggal Tbk (GJTL) yang dari mengalami kerugian sebesar 2,42\% tahun 2015 menjadi mengalami keuntungan (laba) sebesar 4,60\% tahun 2016. Di sisi lain, pada PT Multi Prima Sejahtera Tbk d.h Lippo Enterprises Tbk (LPIN) justru mengalami kerugian yang cenderung sangat meningkat dari rugi sebesar $23,36 \%$ menjadi rugi sebesar $45,18 \%$.

\section{Pembahasan}

Common size (analisis persentase per komponen) merupakan analisis yang dilakukan untuk membandingkan antara komponen yang ada dalam suatu laporan keuangan, baik yang ada di neraca maupun laba rugi (Kasmir, 2016b). Analisis ini dilakukan untuk mengetahui yaitu yang pertama, persentase investasi (komposisi aktiva) pada setiap jenis aktiva, yang dapat membantu suatu perusahaan memberikan gambaran tentang posisi relatif aktiva lancar terhadap aktiva tidak lancar.

Kedua untuk mengetahui struktur permodalan (komposisi pasiva), yang dapat memberikan gambaran mengenai posisi relatif utang perusahaan terhadap modal sendiri. Ketiga untuk mengetahui komposisi biaya terhadap penjualan, yang dapat menggambarkan distribusi atau alokasi setiap Rp.100 penjualan kepada masing-masing elemen biaya dan laba.

Berdasarkan pada hasil penelitian, menunjukkan bahwa komposisi aktiva pada tiga belas perusahaan otomotif yang terdaftar di Bursa Efek Indonesia, hanya terdapat dua perusahaan yang persentase aktiva lancar relatif lebih besar dibandingkan dengan aktiva tidak lancar. Sedangkan sebelas perusahaan otomotif lainnya menggunakan aktiva tidak lancar relatif lebih besar bila dibandingkan dengan aktiva lancar.

Pada aspek likuiditas perusahaan menunjukkan kemampuan perusahaan membayar kewajiban jangka pendek dengan aktiva lancar yang dimilikinya. Terdapat tiga perusahaan yang tingkat likuiditas perusahaan kurang baik karena belum mampu membayar kewajiban jangka pendek dengan aktiva lancar yang dimilikinya. Kondisi ini menunjukkan tingkat likuiditas perusahaan tidak baik. Sedangkan sepuluh perusahaan otomotif lainnya, telah mampu membayar kewajiban jangka pendek dengan aktiva lancar yang dimilikinya. Kondisi ini menunjukkan tingkat likuiditas perusahaan baik (Wiagustini, 2014).

Hasil perhitungan pada pos utang (liabilitas) dan modal sendiri (ekuitas), terdapat enam perusahaan otomotif yang menggunakan struktur permodalan (komposisi pasiva) berasal dari utang (liabilitas) relatif lebih besar dibandingkan dengan modal sendiri (ekuitas). Ini berarti perusahaan tersebut dalam mengalokasikan dana atau modal perusahaan untuk aktiva sebagian besar berasal dari utang (liabilitas). Lebih besarnya sumber modal dari utang dibandingkan dengan modal sendiri akan menimbulkan beban berat bagi perusahaan dan rendahnya margin of safety bagi para kreditur (Jumingan, 2014). Kondisi ini menunjukkan bahwa tingkat solvabilitas pada perusahaan-perusahaan otomotif tersebut akan semakin menurun juga 
karena sumber modal lebih besar (Wiagustini, 2014).

$\mathrm{Di}$ sisi lain, terdapat tujuh perusahaan yang menggunakan struktur permodalan (komposisi pasiva) berasal dari modal sendiri relatif lebih besar bila dibandingkan dengan utang. Ini berarti perusahaan dalam mengalokasikan dana untuk aktiva sebagian besar berasal dari modal sendiri. Lebih besarnya sumber modal dari modal sendiri dibandingkan utang akan meningkatkan margin of safety bagi kreditur dan menguatkan posisi keuangan perusahaan (Jumingan, 2014). Sehingga tingkat solvabilitas yang dimiliki oleh perusahaanperusahaan tersebut juga semakin meningkat (Wiagustini, 2014).

Selain ditinjau dari neraca (laporan posisi keuangan), common size juga ditinjau dari laporan laba rugi. Pada laporan laba rugi, terdapat sepuluh perusahaan yang persentase beban pokok penjualanya turun dan mengakibatkan naiknya gross margin (persentase laba bruto dari nilai penjualan neto). Kondisi ini mencerminkan keberhasilan strategi pemasaran (Jumingan, 2014). Dalam aspek efisiensi, dapat disimpulkan bahwa perusahaan-perusahaan tersebut mengalami peningkatan efisiensi dalam biaya produksi (Wiagustini, 2014).

Pada tiga perusahaan lainnya justru mengalami peningkatan pada persentase beban pokok penjualan dan mengakibatkan turunnya gross margin Kondisi ini mencerminkan tidak berhasilnya strategi pemasaran yang dilakukan oleh perusahaan (Jumingan, 2014). Dalam aspek efisiensi, dapat disimpulkan bahwa perusahaan tersebut mengalami penurunan efisiensi dalam biaya produksi (Wiagustini, 2014).

Pada pos laba bersih, hampir semua perusahaan otomotif mengalami peningkatan pada laba bersihnya, yang mana laba bersih merupakan hasil akhir dari kegiatan usaha yang dijalankan pada suatu periode tertentu. Kondisi tersebut menunjukkan kemampuan perusahaan dalam menghasilkan laba bersih berdasarkan tingkat penjualannya semakin baik sehingga kinerja keuangan perusahaan juga semakin baik. Dengan kata lain, rentabilitas perusahaan-perusahaan tersebut semakin meningkat (Wiagustini, 2014).

Tiga perusahaan otomotif lainnya mengalami penurunan pada laba bersihnya. Perusahaan-perusahaan tersebut mengalami kerugian yang mengakibatkan kemampuan perusahaan menghasilkan laba bersih semakin kurang baik sehingga kinerja keuangan perusahaan menjadi kurang baik juga. Kondisi ini menunjukkan rentabilitas perusahaan semakin menurun (Wiagustini, 2014).

Secara keseluruhan ketigabelas perusahaan otomotif yang terdaftar di Bursa Efek Indonesia (BEI) pada common size neraca menunjukkan kenaikan maupun penurunan setiap posnya, begitu juga pada laporan laba rugi. Analisis ini mendukung penelitian Kholifah (2015), dimana common size menunjukkan kenaikan maupun penurunan pada setiap pos yang dimiliki oleh setiap perusahaan. Hal ini dikarenakan adanya fluktuasi pada setiap jumlah pos neraca dan laporan laba rugi.

\section{SIMPULAN DAN SARAN Simpulan}

Berdasarkan pembahasan pada bab empat, maka dapat disimpulkan bahwa kinerja keuangan dengan menggunakan common size pada perusahaan otomotif yang terdaftar di Bursa Efek Indonesia (BEl) tahun 2016 ditinjau dari neraca, terdapat enam perusahaan otomotif yang mengalokasikan dana untuk aktiva sebagian besar berasal dari utang (liabilitas) sehingga akan menimbulkan beban berat bagi perusahaan dan rendahnya margin of safety bagi kreditur Selain itu, tingkat solvabilitas pada enam perusahaan tersebut semakin menurun. Sedangkan tujuh 
perusahaan otomotif lainnya mengalokasikan dana untuk aktiva sebagian besar berasal dari modal sendiri sehingga dapat meningkatkan margin of safety bagi kreditur dan menguatkan posisi keuangan perusahaan. Jadi dengan kata lain tingkat solvabilitas pada tujuh perusahaan otomotif tersebut semakin meningkat.

Pada kinerja keuangan dengan menggunakan common size pada perusahaan otomotif yang terdaftar di Bursa Efek Indonesia (BEI) tahun 2016 ditinjau dari laporan laba rugi, terdapat sepuluh perusahaan otomotif yang mengalami peningkatan pada kemampuan menghasilkan laba bersih sehingga kinerja keuangan pada sembilan perusahaan tersebut semakin baik serta rentabilitas sepuluh perusahaan otomotif tersebut semakin meningkat. Di sisi lain, tiga perusahaan otomotif lainnya memiliki kinerja keuangan yang kurang baik karena mengalami penurunan pada laba bersihnya sehingga kemampuan perusahaan dalam menghasilkan laba bersih semakin kurang baik. Dengan kata lain, rentabilitas pada tiga perusahaan otomotif tersebut semakin menurun.

\section{Saran}

Berdasarkan uraian pada bab-bab sebelumnya dan pada simpulan, dapat dikemukakan saran untuk pihak perusahaan otomotif diharapkan lebih dapat mengoptimalkan aset yang sudah dimilki oleh perusahaan dan lebih berhati-hati dengan pengambilan keputusan berinvestasi. Dengan melakukan optimalisasi aset diharapkan dapat memacu dan meningkatkan aktifitas perusahaan dan mampu meningkatkan pendapatan sehingga likuiditas perusahaan menjadi lebih baik kedepannya. Selain itu perusahaan diharapkan dapat meningkatkan kinerja keuangan dengan cara meningkatkan laba bersih terutama bagi perusahaanperusahaan otomotif yang mengalami kerugian sehingga tingkat rentabilitas perusahaan nantinya dapat meningkat.
Selain saran untuk pihak perusahaan otomotif, ada juga saran bagi peneliti selanjutnya yang melakukan penelitian sejenis, sebaiknya melakukan penelitian pada perusahaan yang berbeda serta menggunakan periode tahun pengamatan penelitian dan analisis yang lebih banyak sehingga dapat memperoleh hasil penelitian yang baik.

\section{DAFT AR PUST AKA}

Afrianti, Desy. 2016. "Laba Bersih Astra International Merosot Jadi Rp $3,1 \quad$ Miliar". Tersedia pada https://www.money.id/finance/lab a-bersih-astra-internationalmerosot-jadi-rp31-miliar1604266.html (diakses tanggal 24 Maret 2017).

Arifin, Choirul. 2017. "Divisi Otomotif Grup Astra International Tbk Raih Laba Rp 9,2 Triliun, Penjualan AHM Turun". Tersedia pada http://www.tribunnews.com/otom otif/2017/02/27/divisi-otomotifgrup-astra-international-tbk-raihlaba-rp-92-triliun-penjualan-ahmturun (diakses tanggal 24 Maret 2017).

Fahmi, Irham. 2012. Analisis Kinerja Keuangan. Bandung: Alfabeta.

Hanafi, Mamduh dan Abdul Halim. 2009. Analisis Laporan Keuangan. Yogyakarta: UPP STIM YKPN.

Hery. 2012. Analisis Laporan Keuangan. Jakarta: Bumi Aksara.

Husnan, Suad. 2011. Dasar-dasar Manajemen Keuangan. Edisi Keenam. Yogyakarta: UPP STIM YKPN.

Jumingan. 2014. Analisis Laporan Keuangan. Jakarta: PT Bumi.

Kamaludin dan Rini Indriani. 2012. Manajemen Keuangan. Konsep Dasar dan Penerapannnya. Edisi Revisi. Bandung: CV Mandar Maju.

Kasmir. 2016a. Pengantar Manajemen Keuangan. Edisi Kedua. Jakarta: Kencana Prenada Media Group. 
------. 2016b. Analisis Laporan Keuangan. Jakarta: Rajawali Pers.

Kholifah, Binti. 2015. "Analisis Laporan Keuangan dengan Analisis Common Size untuk Membandingkan Kinerja Keuangan Perusahaan pada Kelompok Perusahaan Telekomunikasi yang Terdaftar di Bursa Efek Indonesia (BEI) Tahun 2010-2014". Skripsi (tidak diterbitkan). FKIP_Pendidikan Ekonomi Akuntansi, Universitas Nusantara PGDRI Kediri.

Munawir. 2010. Analisa Laporan Keuangan. Yogyakarta: Liberty. Rochimawati, Romys Binekasri. 2015. "Laba Turun, Perusahaan Sektor Otomotif Ini Bagi Dividen. Tersedia pada http://m.viva.co.id/berita/bisnis/ 7 71529-laba-turun-perusahaansektor-otomotif-ini-bagidividen (diakses tanggal 24 Maret 2017).

Sawir, Agnes. 2005. Analisa Kinerja Keuangan dan Perencanaan Keuangan Perusahaan. Jakarta: PT Gramedia Pustaka Utama.

Wiagustini, Ni Luh Putu. 2014. Manajemen

Keuangan. Denpasar: Udayana University

Press

www.idx.co.id diakses tanggal 3 Mei 2017

www.sahamok.com diakses tanggal 14 Maret 2017 